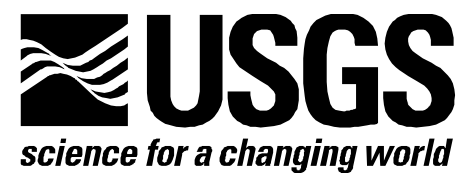

\title{
Complexity of Nearshore Strontium-to-Calcium Ratio Variability in a Core Sample of the Massive Coral Siderastrea siderea Obtained in Coral Bay, St. John, U.S. Virgin Islands
}

By Christopher D. Reich, Ilsa B. Kuffner, T. Don Hickey, Jennifer M. Morrison, and Jennifer A. Flannery

Open-File Report 2013-1092

U.S. Department of the Interior

U.S. Geological Survey 


\section{U.S. Department of the Interior \\ SALLY JEWELL, Secretary}

\section{U.S. Geological Survey \\ Suzette M. Kimball, Acting Director}

U.S. Geological Survey, Reston, Virginia: 2013

For product and ordering information:

World Wide Web: http://www.usgs.gov/pubprod

Telephone: 1-888-ASK-USGS

For more information on the USGS—-the Federal source for science about the Earth, its natural and living resources, natural hazards, and the environment:

World Wide Web: http://www.usgs.gov

Telephone: 1-888-ASK-USGS

Suggested citation:

Reich, C.D., Kuffner, I.B., Hickey, T.D., Morrison, J.M., and Flannery, J.A., 2013, Complexity of nearshore strontiumto-calcium ratio variability in a core sample of the massive coral Siderastrea siderea obtained in Coral Bay, St. John, U.S. Virgin Islands: U.S. Geological Survey Open-File Report 2013-1092, 12 p.

Any use of trade, product, or firm names is for descriptive purposes only and does not imply endorsement by the U.S. Government.

Although this report is in the public domain, permission must be secured from the individual copyright owners to reproduce any copyrighted material contained within this report. 


\section{Contents}

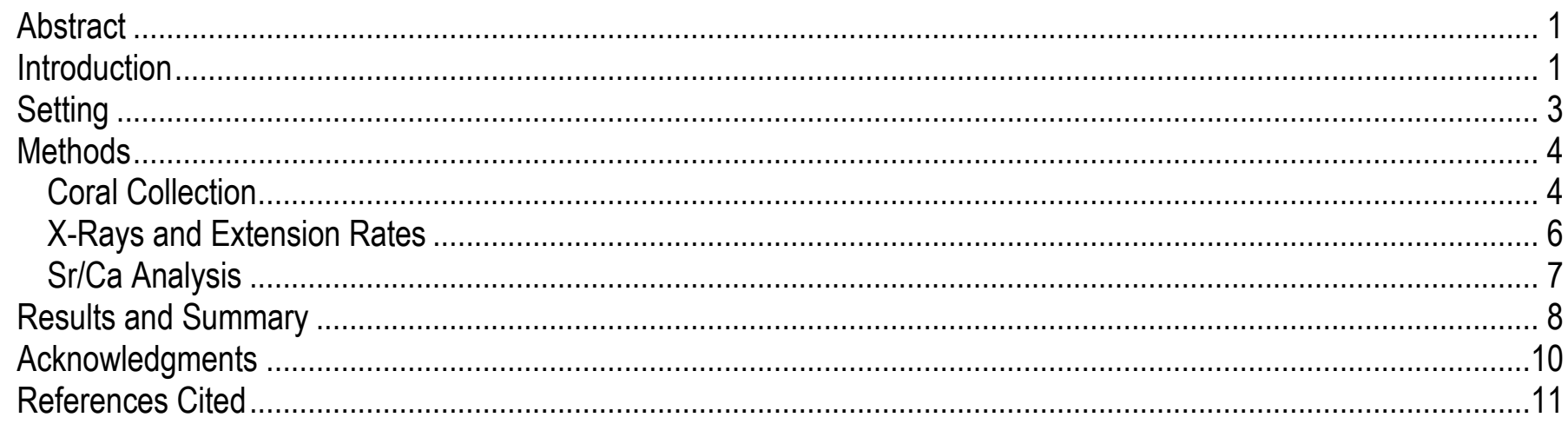

\section{Figures}

1. Satellite image of St. John, U.S. Virgin Islands, shows location of coral cores collected in March 2012.

2. Photographs of a U.S. Geological Survey scientist coring a Siderastrea siderea colony at the U.S. Virgin Islands using a hydraulic-powered drill (A) and extracting the core (B). The Harbor Point (HP-2) coral in St. John, Coral Bay, is shown prior to coring (C) and after coring (D)

3. X-ray of the HP-2 coral slab. An example of a high-density corallite wall that would provide a good path for micro-sampling is identified by arrows.

4. Plot of strontium and calcium (Sr/Ca) for Path 1 (red) and Path 2 (blue) collected from HP-2. Sr/Ca shifts colder (higher $\mathrm{Sr} / \mathrm{Ca}$ ) in the zone where the brown banding occurs

5. Scanned image of the HP-2 coral slab shows drilling Path 1 and a prominent brown-band layer (A) and a strontium/calcium $(\mathrm{Sr} / \mathrm{Ca})$ plot of Path 2 overlain on X-ray (B)

\section{Tables}

1. Collection information for all corals cored in nearshore waters of St. Thomas and St. John, U.S. Virgin Islands 


\section{Conversion Factors}

Inch/Pound to SI

\begin{tabular}{lcl}
\hline \multicolumn{1}{c}{ Multiply } & \multicolumn{1}{c}{ By } & \multicolumn{1}{c}{ To obtain } \\
\hline inch (in.) & Length & \\
inch (in.) & 2.54 & centimeter $(\mathrm{cm})$ \\
foot (ft) & 25.4 & millimeter $(\mathrm{mm})$ \\
mile (mi) & 0.3048 & meter $(\mathrm{m})$ \\
mile, nautical $(\mathrm{nmi})$ & 1.609 & kilometer $(\mathrm{km})$ \\
& 1.852 & kilometer $(\mathrm{km})$ \\
\hline square mile $\left(\mathrm{mi}^{2}\right)$ & Area & \\
\hline
\end{tabular}

SI to Inch/Pound

\begin{tabular}{lll}
\hline \multicolumn{1}{c}{ Multiply } & By & \multicolumn{1}{c}{ To obtain } \\
\hline centimeter $(\mathrm{cm})$ & Length & \\
millimeter $(\mathrm{mm})$ & 0.3937 & inch (in.) \\
meter $(\mathrm{m})$ & 0.03937 & inch (in.) \\
kilometer $(\mathrm{km})$ & 3.281 & foot (ft) \\
kilometer $(\mathrm{km})$ & 0.6214 & mile (mi) \\
& 0.5400 & mile, nautical $(\mathrm{nmi})$ \\
\hline square kilometer $\left(\mathrm{km}^{2}\right)$ & Area & \\
\hline
\end{tabular}

Temperature in degrees Celsius $\left({ }^{\circ} \mathrm{C}\right)$ may be converted to degrees Fahrenheit $\left({ }^{\circ} \mathrm{F}\right)$ as follows:

${ }^{\circ} \mathrm{F}=\left(1.8 \times{ }^{\circ} \mathrm{C}\right)+32$ 


\title{
Complexity of Nearshore Strontium-to-Calcium Ratio Variability in a Core Sample of the Massive Coral Siderastrea siderea Obtained in Coral Bay, St. John, U.S. Virgin Islands
}

\author{
By Christopher D. Reich, Ilsa B. Kuffner, T. Don Hickey, Jennifer M. Morrison, and Jennifer A. Flannery
}

\begin{abstract}
Strontium-to-calcium ratios $(\mathrm{Sr} / \mathrm{Ca})$ were measured on the skeletal matrix of a core sample from a colony of the massive coral Siderastrea siderea collected in Coral Bay, St. John, U.S. Virgin Islands. Strontium and calcium are incorporated into the coral skeleton during the precipitation of aragonite by the coral polyps and their ratio is highly temperature dependent. The robustness of this temperature dependence makes $\mathrm{Sr} / \mathrm{Ca}$ a reliable proxy for sea surface temperature (SST). Details presented from the St. John S. siderea core indicate that terrestrial inputs of sediment and freshwater can disrupt the chemical balance and subsequently complicate the utility of $\mathrm{Sr} / \mathrm{Ca}$ in reconstructing historical SST. An approximately 44-year-long record of Sr/Ca shows that an annual SST signal is recorded but with an increasing $\mathrm{Sr} / \mathrm{Ca}$ trend from 1980 to present, which is likely the result of runoff from the mountainous terrain of St. John. The overwhelming influence of the terrestrial fingerprint on local seawater chemistry makes utilizing Sr/Ca as a SST proxy in nearshore environments very difficult.
\end{abstract}

\section{Introduction}

Coral reefs generally occur between $35^{\circ} \mathrm{N}$ and $32^{\circ} \mathrm{S}$, where water temperature stays within a range from approximately 18 to $31^{\circ} \mathrm{C}$ (Druffel, 1997; Veron, 2000; Corrège, 2006). This relatively narrow range in sea surface temperature (SST) tolerance allows corals to be useful as indicators of paleoclimate. Many of the shallow-water coral reefs $(<25$-meter $(\mathrm{m})$ water depth) in the Caribbean Sea and tropical Atlantic Ocean have been accumulating since 4,000 to 6,000 years ago when rising sea level flooded the shallow banks where modern-day corals are found (Lighty and others, 1978; Toscano and Lundberg, 1998; Balsillie and Donoghue, 2004).

Current understanding of climate variability has been limited by the short duration of instrumental temperature records. Since corals can live for long periods of time and grow in areas that are relatively consistent with respect to temperature and salinity, they are ideal for retrospectively extending instrumental SST records. Corals secrete skeletons composed of calcium carbonate $\left(\mathrm{CaCO}_{3}\right)$, in the form of the mineral aragonite, through a process known as skeletogenesis (Beck and others, 1992; Druffel, 1997; Corrège, 2006; Lough and Cooper, 2011). During the secretion of aragonite, corals substitute trace elements such as barium $(\mathrm{Ba})$, lead $(\mathrm{Pb})$, magnesium $(\mathrm{Mg})$, manganese $(\mathrm{Mn})$, and 
strontium (Sr) in place of calcium (Ca) (Druffel, 1997; Corrège, 2006). Studies on skeletal strontium-tocalcium $(\mathrm{Sr} / \mathrm{Ca})$ suggest that the variability of $\mathrm{Sr}$ in the aragonite is highly dependent upon the temperature of seawater (Weber, 1973; Smith and others, 1979; Beck and others, 1992; Alibert and McCulloch, 1997; Swart and others, 2002; Corrège, 2006). The warmer the water, the less $\mathrm{Sr}$ is incorporated into the aragonite matrix; therefore, lower Sr/Ca equates to warmer SST and higher $\mathrm{Sr} / \mathrm{Ca}$ to cooler SST (Weber, 1973; Smith and others, 1979). Corals also deposit annual high- and low-density bands, akin to tree rings, which are useful in age-dating the coral (Lough, 2008; Lough and Cooper, 2011). The measurement from one high-density band to the next is the annual linear extension rate, which can vary from year to year due to various environmental factors, such as thermal (cold or hot) stress, disease, water quality, or predation (fish or boring organisms).

The application of $\mathrm{Sr} / \mathrm{Ca}$ to paleothermometry is not without caveats. Modern-day technology and precise measurement of $\mathrm{Sr}$ and $\mathrm{Ca}$ have reduced the errors of past studies; however, there are other factors that can affect $\mathrm{Sr}$ and $\mathrm{Ca}$ concentration such as species-specific partition coefficients, metabolism, growth rate, other biological parameters known as "vital effects," sampling techniques, and local seawater Sr/Ca variability (Smith and others, 1979; DeVilliers and others, 1994; Swart and others, 2002; DeLong and others, 2011, Kuffner and others, 2012). The goal of Sr/Ca thermometry is to measure the elemental concentration of $\mathrm{Sr}$ and $\mathrm{Ca}$ obtained from high-resolution sampling (closely spaced samples) of the coral skeleton and calibrate the $\mathrm{Sr} / \mathrm{Ca}$ results with local surface water temperature data so that a calibration equation can be calculated. This assumes that local seawater $\mathrm{Sr} / \mathrm{Ca}$ is conservative and stable. The calibration equation is then applied to the entire coral $\mathrm{Sr} / \mathrm{Ca}$ record to calculate historical SST.

Coral cores from the U.S. Virgin Islands were collected for use in retrospective studies on climate variability using strontium-to-calcium ratios as a proxy for SST. Collection of cores from the U.S. Virgin Islands (St. Thomas and St. John) provided specimens from a tropical region of the Caribbean Sea, which will be compared to existing results from coral cores of the same species collected from the subtropical region in the Florida Keys (U.S.A.). This document reports on Sr/Ca data obtained from a core sample from a single colony of the massive coral Siderastrea siderea collected from Harbor Point (Coral Bay) in eastern St. John, U.S. Virgin Islands (fig. 1). 


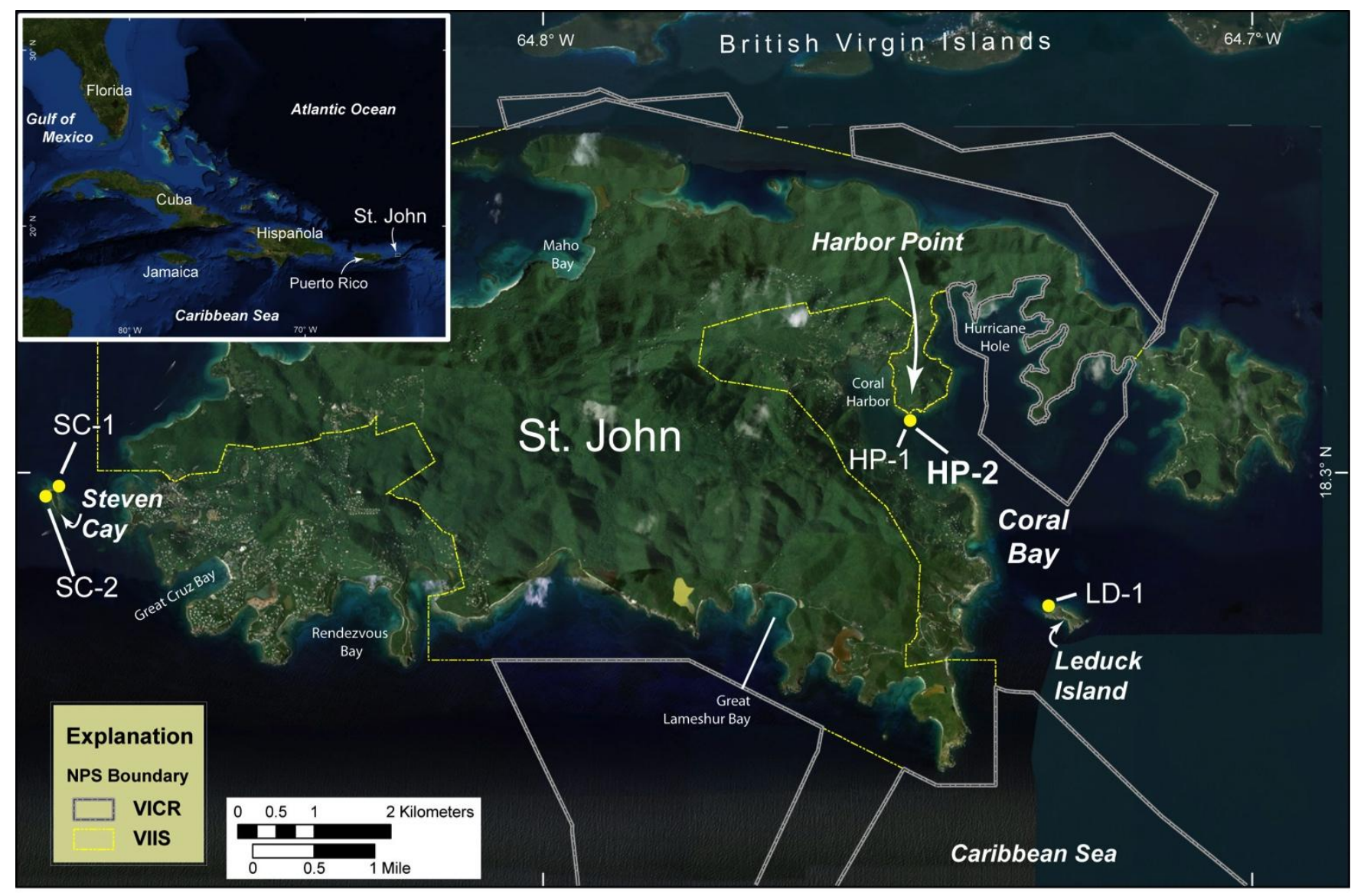

Figure 1. Satellite image of St. John, U.S. Virgin Islands, shows location of coral cores collected in March 2012. The Siderastrea siderea HP-2 (Harbor Point) core, discussed in this report, is located between Coral Harbor and Coral Bay along the eastern shore of St. John. NPS, National Park Service; VICR, Virgin Islands Coral Reef National Monument; VIIS, Virgin Islands National Park.

\section{Setting}

St. John is located at approximately $18.3^{\circ} \mathrm{N}, 64.8^{\circ} \mathrm{W}$, in the island arc chain of the eastern Caribbean Sea (fig. 1). The island of St. John encompasses an area of $\sim 52$ square kilometers and is mountainous with a maximum elevation of 380 m (Rankin, 2002; Hall and KellerLynn, 2010). The population of St. John is approximately 4,170 (2010 census), but more than 400,000 tourists visit the island annually (Hall and KellerLynn, 2010). The Virgin Islands National Park (VIIS), established in 1956, covers over 60 percent (7,000 + acres) of St. John (fig. 1; http://www.nps.gov/viis/). In 2001, the VIIS expanded to include a 3-mile-wide belt of submerged land, and the Virgin Islands Coral Reef National Monument (VICR) was established (Hall and KellerLynn, 2010; http://www.nps.gov/vicr/).

The geology of the U.S. Virgin Islands is composed of the Lameshur Volcanic-Intrusive Complex of the Cretaceous Period (Rankin, 2002). This geologic complex consists of basalts, andesite, and minor calcareous rocks and cherts that were uplifted and tilted as the Caribbean Plate moved from the western Pacific to its current position (Rankin, 2002). Though the Virgin Islands are situated within a 
seismically active region, recent activity has subsided, and, unlike Cuba or Puerto Rico, there is no evidence of uplift or fault scarps since the late Pleistocene Epoch (Rankin, 2002).

The Harbor Point (HP-2) core was collected along the eastern end of St. John, within Coral Bay, off a projecting land mass known as Harbor Point (fig. 1). Coral Bay is a large, multi-lobed embayment that is fringed by mangroves, contains fringing coral reefs, and is home to $~ 634$ people (2010 census; http://www.nps.gov/viis/). Both Coral Bay, south of Harbor Point, and Coral Harbor, north of Harbor Point, have been subjected to increased sedimentation over the past several decades due to road construction, residential and commercial construction, and other anthropogenic activities (Brooks and others, 2007; Gray and others, 2012). Enhanced sedimentation occurs as a result of these land-use changes during large precipitation events, such as hurricanes. Bottom sediments transition from terrigenous (volcanic derived) at the head of Coral Harbor, to open marine (carbonate derived) near the center of Coral Bay (Brooks and others, 2007). Harbor Point is in the transition zone for the mixing of terrigenous and carbonate sediments.

\section{Methods}

\section{Coral Collection}

Site selection and identification of potential coral colonies for sampling occurred in September 2011, at which time thermographs were deployed near prospective, healthy, massive corals.

Thermographs were deployed in water depths $<5 \mathrm{~m}$ at locations near Flat Cays in St. Thomas and near Leduck Island and Harbor Point in St. John.

These sites were revisited in March 2012. The largest and healthiest corals from two species, Siderastrea siderea and Montastraea faveolata, were identified at the prospective locations and cored along the primary growth axis. In addition, a single Diploria strigosa colony was cored near Steven Cay on the western shore of St. John (fig. 1). In total, eight coral heads were cored from the three species (see table 1 for core statistics and Reich and others, 2012, for further details). Corals were drilled using a Stanley DL07 underwater hydraulic drill and 4-inch-diameter core barrel (fig. 2A) using similar methods as Reich and others (2009) and Hickey and others (2012). A single core was collected from each coral head (fig. 2B). Cores were collected at three locations on St. John: Steven Cay, Leduck Island, and Harbor Point (fig. 1). This report, however, only discusses the HP-2 core collected from Harbor Point located in Coral Bay, St. John. The HP-2 core was collected from the massive coral S. siderea (fig. 2C, table 1). 


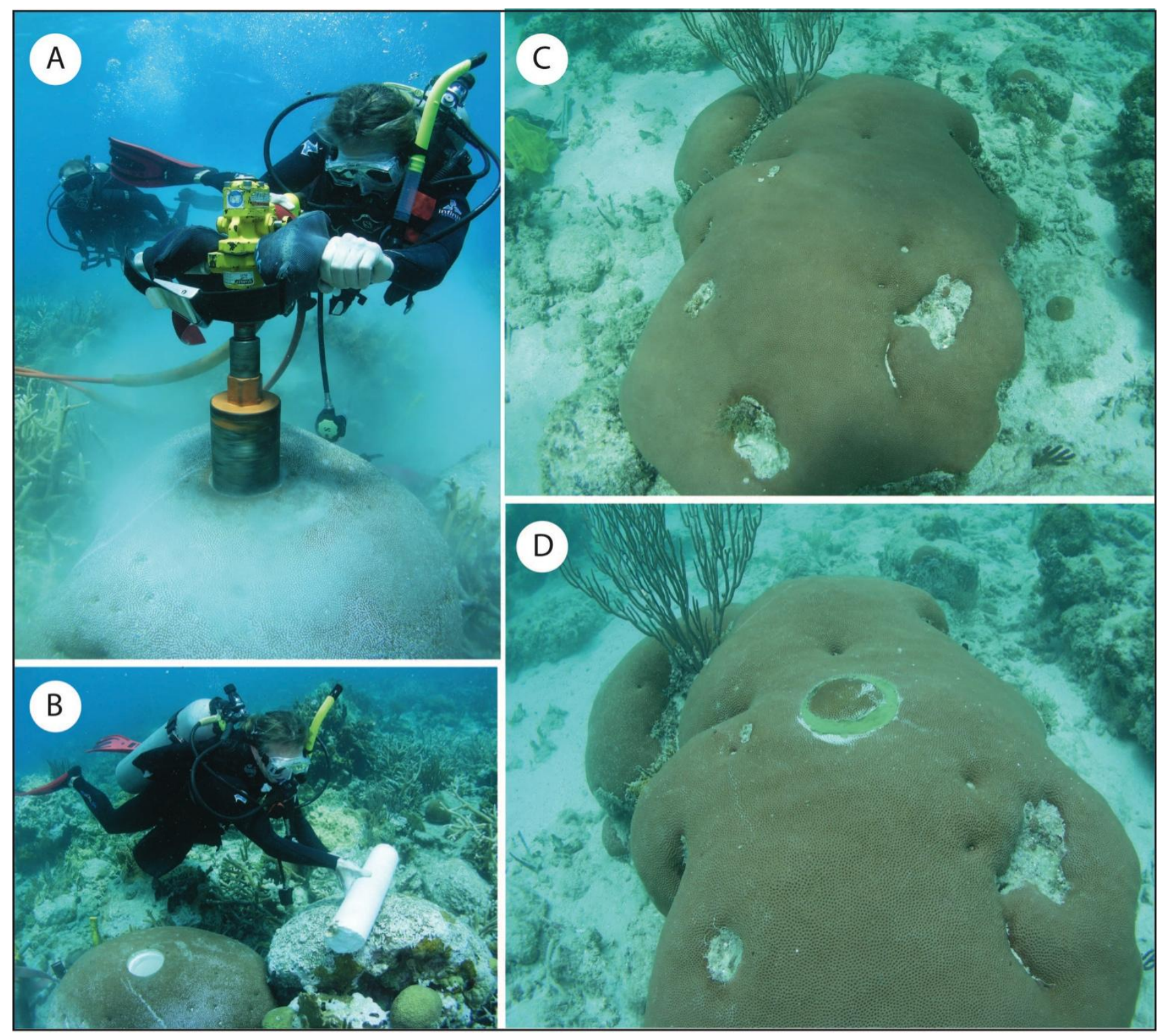

Figure 2. Photographs of a U.S. Geological Survey scientist coring a Siderastrea siderea colony at the U.S. Virgin Islands using a hydraulic-powered drill (A) and extracting the core (B). The Harbor Point (HP-2) coral in St. John, Coral Bay, is shown prior to coring (C) and after coring (D). A live plug was inserted and epoxied into place after the core was extracted (D). Plug diameter is 10.2 centimeters. 
Table 1. Collection information for all corals cored in nearshore waters of St. Thomas and St. John, U.S. Virgin Islands. Details for the Harbor Point (HP-2) core collected on St. John are discussed in this report.

[Dates are shown by month/day/year. USVI, U.S. Virgin Islands; N, north; W, west; cm, centimeter; m, meter]

\begin{tabular}{|l|c|c|c|c|c|c|c|c|}
\hline Date & $3 / 16 / 12$ & $3 / 17 / 12$ & $3 / 17 / 12$ & $3 / 19 / 12$ & $3 / 20 / 12$ & $3 / 20 / 12$ & $3 / 21 / 12$ & $3 / 21 / 12$ \\
\hline Site ID & FC-1 & FC-2 & FC-3 & LD-1 & HP-1 & HP-2 & SC-1 & SC-2 \\
\hline Location & Flat Cays & Flat Cays & Flat Cays & Leduck Island & $\begin{array}{c}\text { Harbor } \\
\text { Point }\end{array}$ & $\begin{array}{c}\text { Harbor } \\
\text { Point }\end{array}$ & $\begin{array}{c}\text { Steven } \\
\text { Cay }\end{array}$ \\
\hline USVI island & St. Thomas & St. Thomas & St. Thomas & St. John & St. John & St. John & St. John & St. John \\
\hline Latitude $(\mathbf{N})$ & 18.3166 & 18.3162 & 18.3161 & 18.3175 & 18.3399 & 18.3399 & 18.3316 & 18.3306 \\
\hline Longitude $(\boldsymbol{W})$ & 64.9882 & 64.9883 & 64.9882 & 64.6902 & 64.7054 & 64.7054 & 64.807 & 64.8082 \\
\hline Total core length $(\mathbf{c m})$ & 77.5 & 60.3 & 100.3 & 35.6 & 165.1 & 92.1 & 80.0 & 54.6 \\
\hline Water depth $(\mathbf{m})$ & 4.85 & 4.24 & 4.54 & 3.63 & 2.72 & 3.93 & 3.63 & 0.3 \\
\hline Coral species & S. siderea & S. siderea & faveolata & S. siderea & M. faveolata & S. siderea & S. siderea & strigosa \\
\hline
\end{tabular}

aPresented in this report.

A short plug with live coral tissue was collected from the base of the coral head and inserted into the open hole where the core was extracted. This method, similar to that described by Hudson (1983), was implemented in order to speed up the recovery time of the coral. The short plug from the base was placed in the hole and epoxied into place (fig. 2D). In most situations the dense skeletons of S. siderea and $D$. strigosa complicated and prevented the live tissue core plug transplant method. Since the live tissue plug could not be used for many of the S. siderea and D. strigosa corals, a precast cement plug was epoxied within the hole so that no live tissue edges were left exposed.

\section{X-Rays and Extension Rates}

Cores were sectioned along the primary growth axis into 4-millimeter-thick slabs. Multiple $(\sim 3)$ slabs were obtained because corallite walls tend to migrate over time and therefore one slab may have a more continuous path for geochemical sampling. Slabs were placed in deionized water and ultrasonicated using a Branson Sonifier with probe to remove fine-grained material. Slabs were allowed to completely dry prior to being X-rayed. The HP-2 slab identified for sampling was placed on a phosphor plate and X-rayed at 55 kilovolts and 2.5 milli-Ampere-seconds (mAs). The distance between the plate and the X-ray source was 79 centimeters $(\mathrm{cm})$. The plate was scanned on an iCR3600+ scanner at 254 dots per inch (dpi) resolution $\left(10\right.$ pixels $\left.\mathrm{mm}^{-1}\right)$ and processed on iCRco, Inc. software. The X-ray (fig. 3) was exported as both 16-bit Tagged Image File Format (TIFF) and native Digital Imaging and Communications in Medicine (DICOM) file formats.

X-ray images were examined for high- and low-density bands. A couplet of high- and lowdensity bands (light and dark) on the X-ray is equivalent to one year of growth. Adobe Photoshop was used to measure the distance between couplets. An estimate of annual growth, or linear extension, rate over the length of the coral slab was calculated (Hudson and others, 1976; Helmle and others, 2011). Extension rate calculations are necessary to calculate a proper sampling interval for coral powder collection via a micro-drill. A minimum of 12 samples per year are necessary to potentially capture the annual seasonal cycle in $\mathrm{Sr} / \mathrm{Ca}$. However, there is a trade-off between number of samples per year and quantity of material; increased sampling rate per year equates to less coral material per sample for $\mathrm{Sr} / \mathrm{Ca}$ analyses. 


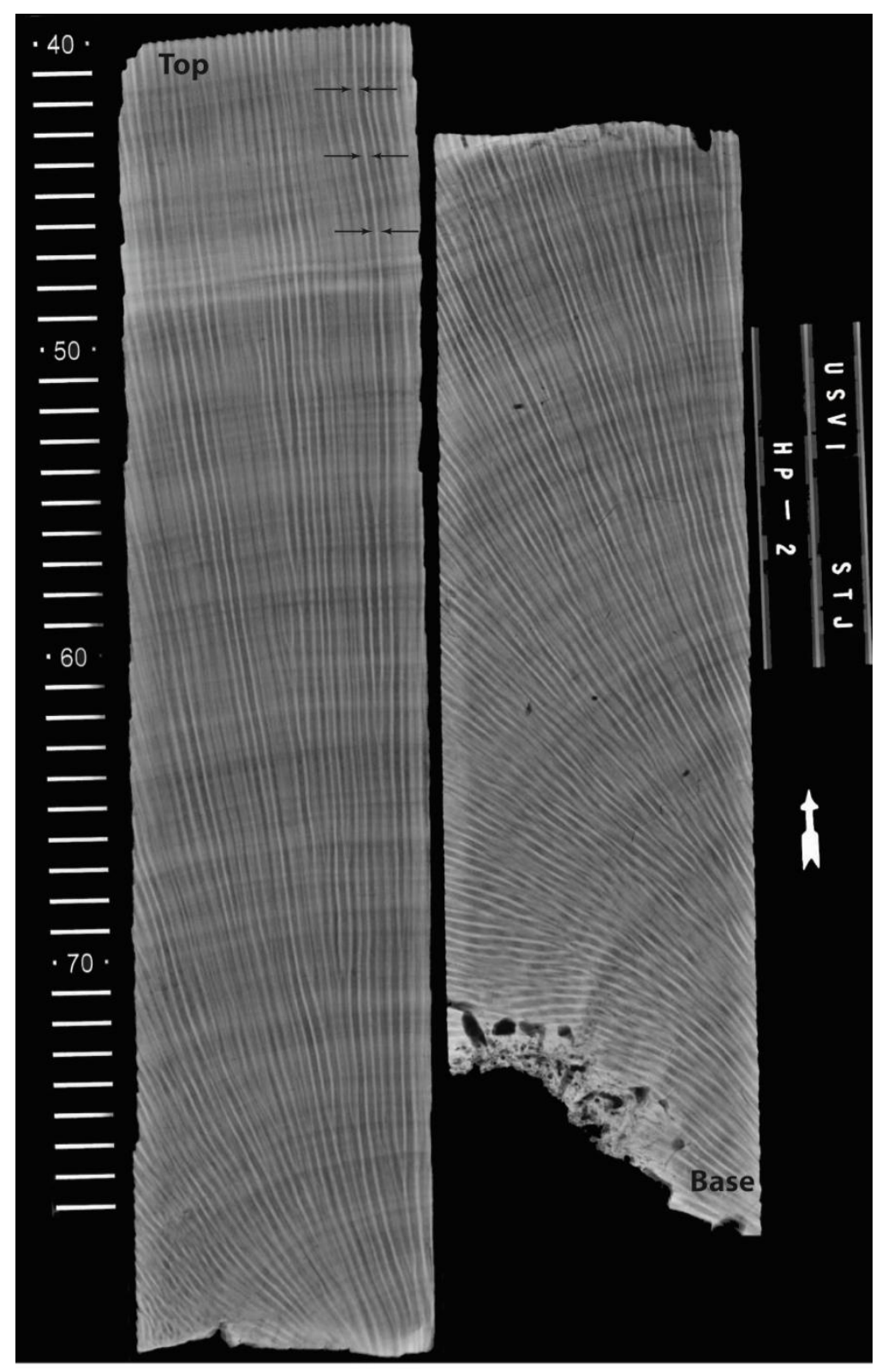

Figure 3. X-ray of the HP-2 coral slab. An example of a high-density corallite wall that would provide a good path for micro-sampling is identified by arrows. Note faint high- and low-density bands on the X-ray. Scale is in centimeters.

\section{$\mathrm{Sr} / \mathrm{Ca}$ Analysis}

The X-ray image of the HP-2 coral slab was used to determine the appropriate path for microsampling. Generally, the best path to sample is the longest continuously growing corallite wall that appears as a longitudinal high-density band on the X-ray. The drilling path was traced along the corallite wall using Adobe Illustrator (fig. 3). The traced path was exported from Adobe Illustrator as a Drawing Exchange Format (DXF) file and imported into the SuperCam software operating the XYZ drill. 
A 1 millimeter ( $\mathrm{mm}$ ) tungsten carbide-tipped drill bit was used to sample the coral. Coral powder was collected along the growth axis in increments of $0.25 \mathrm{~mm}$ (Path 1) and $0.20 \mathrm{~mm}$ (Path 2) to a depth of $1.25 \mathrm{~mm}$, then placed in pre-labeled micro-centrifuge tubes. Based on X-ray-determined linear extension rates, approximately 12 to 16 samples per year were collected at this sampling increment. A divot in the skeleton was made every 20 samples for future referencing and is visible on subsequent

$\mathrm{X}$-ray images.

Sr and Ca were measured on a PerkinElmer 7300 Dual View Inductively Coupled Plasma Optical Emission Spectrometer (ICP-OES) at the U.S. Geological Survey St. Petersburg Coastal and Marine Science Center (SPCMSC). For sample analyses, $\sim 100$ micrograms $(\mu \mathrm{g})$ of coral powder was weighed, placed into an ICP tube, and acidified with 2 percent nitric acid $\left(\mathrm{HNO}_{3}\right)$ to an approximate concentration of 20 parts per million (ppm) Ca. To measure precision and correct for potential instrumental drift, an internal gravimetrical standard (IGS) solution was measured for $\mathrm{Sr} / \mathrm{Ca}$ before and after each dissolved coral sample (Schrag, 1999). The average corrected IGS precision for Sr/Ca was 0.009 millimoles per mole $(\mathrm{mmol} / \mathrm{mol})(1 \sigma, \mathrm{n}=205)$. A second standard-homogenized powder from the coral Porites lutea (PL) - was analyzed for Sr/Ca to test for any potential matrix effects. The PL standard had an average corrected precision of $0.019 \mathrm{mmol} / \mathrm{mol}(1 \sigma, \mathrm{n}=297)$.

\section{Results and Summary}

Extension rate (ER) measurements on HP-2 were difficult because the $S$. siderea coral collected from St. John deposited a very dense skeletal matrix (fig. 3). The dense composition made discerning annual banding (contrast between high- and low-density band couplets) challenging, even after making brightness and contrast adjustments to the X-ray image. Average linear extension rate, based on X-ray measurements, for the full length of the core $(92.1 \mathrm{~cm})$ was 0.40 centimeters per year $(\mathrm{cm} / \mathrm{yr})(\mathrm{n}=155)$. This ER dates the coral base to approximately the year 1782 ( 230 years old).

In addition to measuring high- and low-density band couplets on X-rays, we measured the distance between the presumed annual peaks on the $\mathrm{Sr} / \mathrm{Ca}$ curve. Extension rates based on X-ray measurements for the top $12 \mathrm{~cm}$ ranged from 0.32 to $0.79 \mathrm{~cm} / \mathrm{yr}$ with an average of $0.51 \mathrm{~cm} / \mathrm{yr}(\mathrm{n}=24)$. At $12 \mathrm{~cm}$ from the top of the core, the last sample would have been collected at $\sim 1989$ ( 23 years ago). In contrast, ER based on $\mathrm{Sr} / \mathrm{Ca}$ peaks, for the top $12 \mathrm{~cm}$, ranged from 0.12 to 0.46 $\mathrm{cm} / \mathrm{yr}$, with an average of $0.26 \mathrm{~cm} / \mathrm{yr}(\mathrm{n}=45)$. The sampling period, based on ER calculated from $\mathrm{Sr} / \mathrm{Ca}$ peaks, would therefore range from 2012 to $\sim 1968$ ( 44 years).

The difference in average ER $(0.21 \mathrm{~cm} / \mathrm{yr})$ between the two methods is cause for concern because sampling rate is based on these values, where minimum sampling density is 12 samples per year and ideal is $\sim 20$ samples per year. The slower linear extension rates, based on the $\mathrm{Sr} / \mathrm{Ca}$ measurements, indicate that the goal of obtaining a minimum of 12 samples per year was marginally achieved and that by recalculating the actual average sampling rate, we only managed to sample at $\sim 10$ samples per year for Path $1(0.25 \mathrm{~mm} / \mathrm{sample})$ and $\sim 13$ samples per year $(0.20 \mathrm{~mm} / \mathrm{sample})$ for Path 2 . Both of these sampling rates are at the minimal range for capturing full seasonal range in the $\mathrm{Sr} / \mathrm{Ca}$ record.

Two overlapping paths were drilled to confirm $\mathrm{Sr} / \mathrm{Ca}$ results and to observe any variation in results from changing the sampling rate. Annual $\mathrm{Sr} / \mathrm{Ca}$ cyclicity is best captured in the $\mathrm{Sr} / \mathrm{Ca}$ record from Path 2, but its continuity over time is influenced (controlled) by external anthropogenic sources (figs. 4, 5). A typical open-ocean $\mathrm{Sr} / \mathrm{Ca}$ record from $S$. siderea in the Dry Tortugas (Florida Keys, U.S.A.) has no mean shift and annual cycles are distinct and highly correlative to SST (for example, see DeLong and others, 2011). Path 2, with a higher sampling resolution than Path 1, shows a slightly more prominent 
annual cycle in $\mathrm{Sr} / \mathrm{Ca}$. Annual $\mathrm{Sr} / \mathrm{Ca}$ cycles for both sampling paths indicate a cool water signal (higher $\mathrm{Sr} / \mathrm{Ca}$ ) that began in $\sim 1980$ at the start of the brown band and thereafter begin to show SST warming to the present (figs. 4 and 5B).

$\mathrm{Sr} / \mathrm{Ca}$ in Coral

(HP-2, Siderastrea siderea)

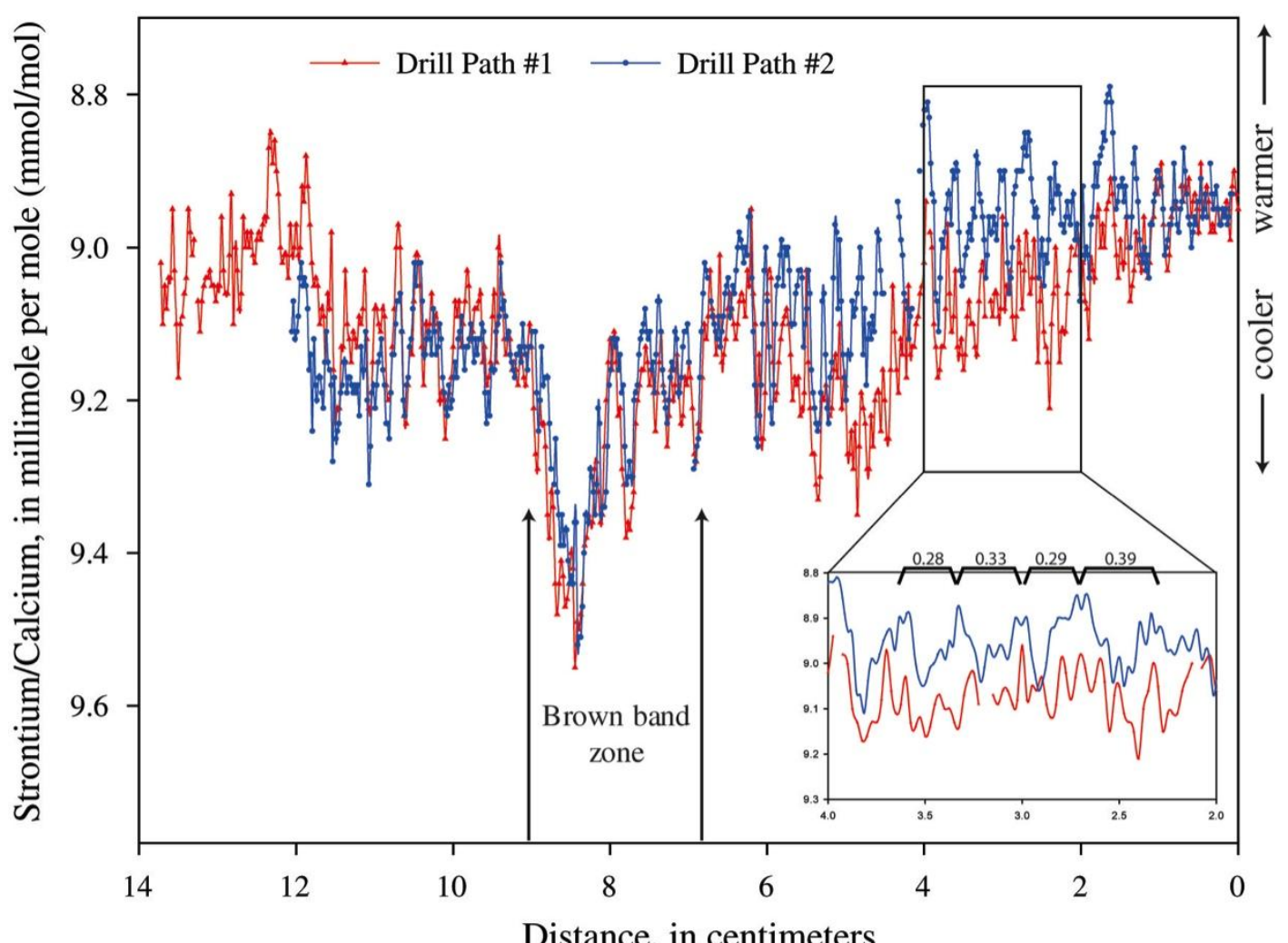

Figure 4. Plot of strontium and calcium (Sr/Ca) for Path 1 (red) and Path 2 (blue) collected from HP-2. Sr/Ca shifts colder (higher $\mathrm{Sr} / \mathrm{Ca}$ ) in the zone where the brown banding occurs. Bottom right graph is an expanded view of the 2- to 4-centimeter interval that shows the annual cycles of $\mathrm{Sr} / \mathrm{Ca}$. The distance between annual cycles (values in centimeters per year shown above the brackets) for Path 2 (blue) represents the linear extension rate for HP-2.

$\mathrm{Sr} / \mathrm{Ca}$ results from HP-2 show the complexity of using $\mathrm{Sr} / \mathrm{Ca}$ as an SST proxy in the nearshore environment (fig. 5). Utilization of $\mathrm{Sr} / \mathrm{Ca}$ as a proxy for SST is ideal for locations possessing few extraneous inputs such as terrestrial discharge of sediments and freshwater (DeLong and others, 2011). HP-2 is located in Coral Bay, near the mouth of one of the largest catchment areas on St. John. During heavy rainfall events, runoff of sediment-laden water flows into Coral Harbor and into the northern portions of Coral Bay (Brooks and others, 2007). These inputs can influence the chemistry of the surface water, impacting the $\mathrm{Sr} / \mathrm{Ca}$ values of the deposited aragonite skeletal matrix. In addition, sediment is also occasionally incorporated in the skeleton, as seen in HP-2 (fig. 5A). The brown band that occurs between 7 and $9 \mathrm{~cm}$ down core was most likely the result of a severe runoff event leading to very turbid waters inundating the corals for several days. Assuming this scenario, the sediment would have been heavy enough to blanket the corals for an extended period of time but not severe enough to result in complete 
mortality. Over time the sediment would then have been incorporated into the skeletal matrix. Results from the HP-2 core indicate that $\mathrm{Sr} / \mathrm{Ca}$ is a challenging proxy for retrospective SST studies in nearshore corals because of the complexities in surface-water chemistry due to the influence of terrestrial runoff.

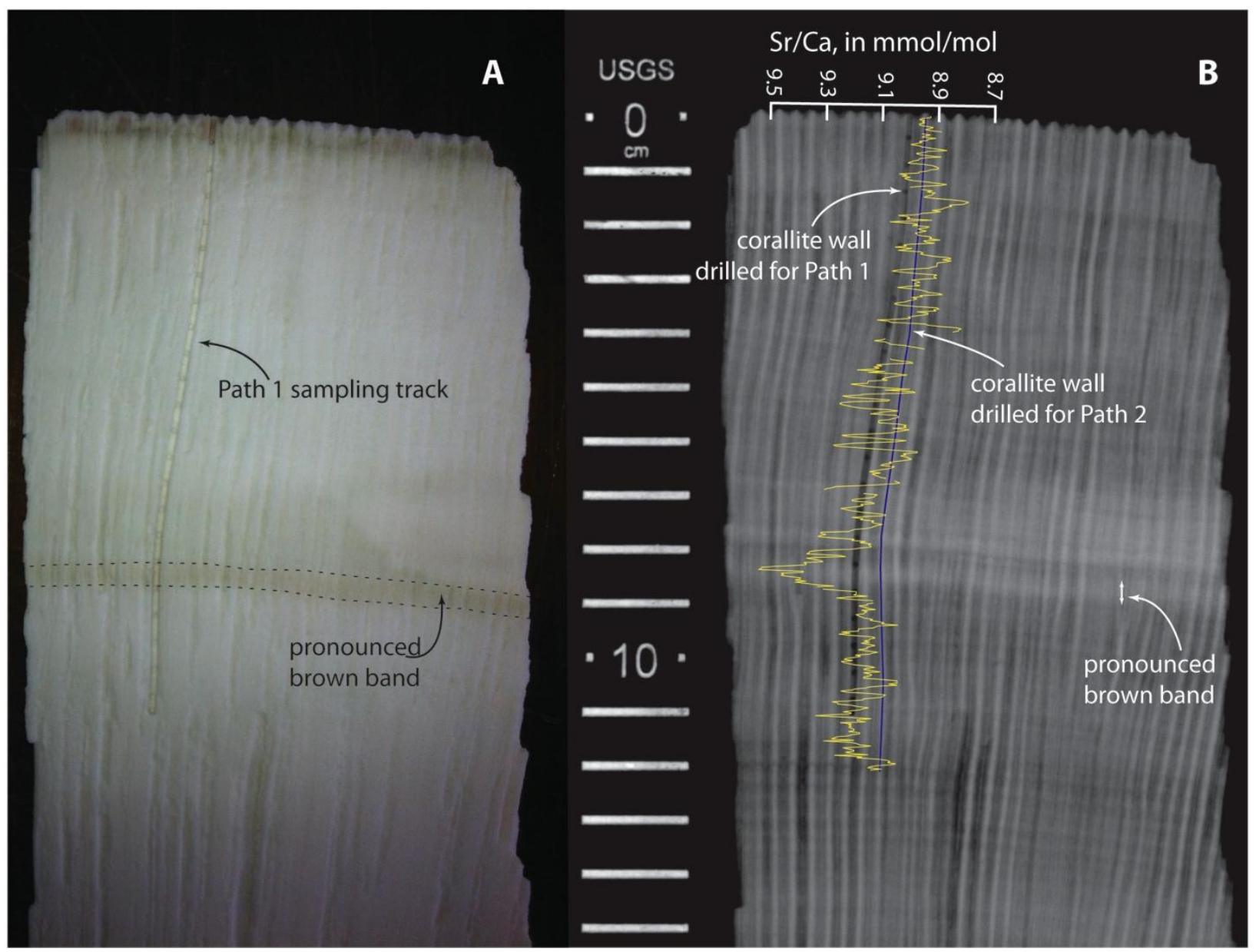

Figure 5. Scanned image of the HP-2 coral slab shows drilling Path 1 and a prominent brown-band layer (A) and a strontium/calcium (Sr/Ca) plot of Path 2 overlain on X-ray (B). Plotting the $\mathrm{Sr} / \mathrm{Ca}$ on the X-ray shows the large deviation within the brown-band layer. Scale is in centimeters; millimoles per mole is shown as $\mathrm{mmol} / \mathrm{mol}$.

\section{Acknowledgments}

The Department of the Interior Southeast Climate Science Center and U.S. Geological Survey Coastal and Marine Geology Program funded this project. Many thanks to Tyler Smith, Steve Prosterman, Rick Nemeth, and Kevin Brown at the University of the Virgin Islands, St. Thomas, for logistics support and to Randy Fish and the staff at the Virgin Islands Environmental Research Station/Clean Islands International on St. John for lodging and access to the boat dock. This project was conducted under U.S. Virgin Islands Territory Government Permit \#001-122. Many thanks to the multiple reviewers who improved this report. 


\section{References Cited}

Alibert, C., and McCulloch, M.T., 1997, Strontium/calcium ratios in modern Porites corals from the Great Barrier Reef as a proxy for sea surface temperature-Calibration of the thermometer and monitoring of ENSO: Paleoceanography, v. 12, no. 3, p. 345-363.

Balsillie, H.H., and Donoghue, J.F., 2004, High resolution sea-level history for the Gulf of Mexico since the last glacial maximum: Florida Geological Survey, Report of Investigations Number 103, Tallahassee, Florida, 66 p.

Beck, J.W., Edwards, R.L., Ito, E., Taylor, F.W., Recy, J., Rougerie, F., Joannot, P., and Henin, C., 1992, Sea-surface temperature from coral skeletal strontium/calcium ratios: Science, v. 257, no. 5070, p. 644-647.

Brooks, G.R., Devine, B., Larson, R.A., and Rood, B.P., 2007, Sedimentary development of Coral Bay, St. John, USVI-A shift from natural to anthropogenic influences: Caribbean Journal of Science, v. 42, no. 2, p. 226-243.

Corrège, T., 2006, Sea surface temperature and salinity reconstruction from coral geochemical tracers: Paleogeography, Paleoclimatology, Paleoecology, v. 232, p. 408-428.

DeLong, K.L., Flannery, J.A., Maupin, C.R., Poore, R.Z., and Quinn, T.M., 2011, A coral Sr/Ca calibration and replication study of two massive corals from the Gulf of Mexico: Paleogeography, Paleoclimatology, Paleoecology, v. 307, p. 117-128.

DeVilliers, S., Shen, G.T., and Nelson, B.K., 1994, The Sr/Ca-temperature relationship in coralline aragonite-Influence of variability in $(\mathrm{Sr} / \mathrm{Ca})_{\text {seawater }}$ and skeletal growth parameters: Geochimica et Cosmochimica Acta, v. 58, p. 197-208.

Druffel, E.R.M., 1997, Geochemistry of corals-Proxies of past ocean chemistry, ocean circulation, and climate: Proceedings of the National Academy of Sciences, v. 94, p. 8354-8361.

Gray, S.C., Sears, W., Kolupski, M.L., Hastings, Z.C., Przyuski, N.W., Fox, M.D., and DeGrood, A., 2012, Factors affecting land-based sedimentation in coastal bays, US Virgin Islands: Proceedings of the $12^{\text {th }}$ International Coral Reef Symposium, Cairns, Australia, 9-13 July 2012, session 21A, Watershed management and reef pollution.

Hall, K., and KellerLynn, K., 2010, Virgin Islands National Park-Geologic resources inventory report: Natural Resource Report NPS/NRPC/GRD/NRR—2010/226. National Park Service, Fort Collins, Colorado, 44 p.

Helmle, K.P., Dodge, R.E., Swart, P.K., Gledhill, D.K., and Eakin, C.M., 2011, Growth rates of Florida corals from 1937 to 1996 and their response to climate change: Nature Communications, 2:215, doi: 10.1038/ncomms 1222 (2011), 6 p.

Hickey, T.D., Reich, C.D., Delong, K.L., Poore, R.Z., and Brock, J.C., 2012, Holocene core logs and site methods for modern reef and head-coral cores-Dry Tortugas National Park, Florida: U.S. Geological Survey Open-File Report 2012-1095, 34 p.

Hudson, J.H., 1983, Growth history of Montastraea annularis at Looe Key National Marine Sanctuary, Florida, chap. 5 of Bohnsack, J.A., ed., Resource survey of Looe Key National Marine Sanctuary: NOAA Technical Memorandum NMFS-SEFSC-478, p. 91-111.

Hudson, J.H., Shinn, E.A., Halley, R.B., and Lidz, B.H., 1976, Sclerochronology-A tool for interpreting past environments: Geology, v. 4, p. 361-364.

Kuffner, I.B., Jokiel, P.L., Rodgers, K.S., Andersson, A.J., and Mackenzie, F.T., 2012, An apparent "vital effect" of calcification rate on the $\mathrm{Sr} / \mathrm{Ca}$ temperature proxy in the reef coral Montipora capitata: Geochemistry, Geophysics, Geosystems, v. 13, no. 8, doi:10.1029/2012GC004128.

Lighty, R.G., Macintyre, I.G., and Stuckenrath, R., 1978, Submerged early Holocene barrier reef southeast Florida shelf: Nature, v. 275, p. 59-60. 
Lough, J.M., 2008, Coral calcification from skeletal records revisited: Marine Ecology Progress Series, v. 373, p. 257-264.

Lough, J.M., and Cooper, T.F., 2011, New insights from coral growth band studies in an era of rapid environmental change: Earth-Science Reviews, v. 108, p. 170-184.

Rankin, D.W., 2002, Geology of St. John, U.S. Virgin Islands: U.S. Geological Survey Professional Paper 1631, $42 \mathrm{p}$.

Reich, C.D., Hickey, T.D., DeLong, K.L., Poore, R.Z., and Brock, J.C., 2009, Holocene core logs and site statistics for modern patch-reef cores, Biscayne National Park, Florida: U.S. Geological Survey Open-File Report 2009-1246, 26 p.

Reich, C., Streubert, M., Dwyer, B., Godbout, M., Muslic, A., and Umberger, D., 2012, St. Petersburg Coastal and Marine Science Center's Core Archive Portal: U.S. Geological Survey Data Series 626, available at http://pubs.usgs.gov/ds/626/.

Schrag, D.P., 1999, Rapid analysis of high-precision $\mathrm{Sr} / \mathrm{Ca}$ ratios in corals and other marine carbonates: Paleoceanography, v. 14, no. 2, p. $97-102$.

Smith, S.V., Buddemeier, R.W., Redalje, R.C., and Houck, J.E., 1979, Strontium-calcium thermometry in coral skeletons: Science, v. 204, no. 4391, p. 404-407.

Swart, P.K., Elderfield, H., and Greaves, M.J., 2002, A high-resolution calibration of Sr/Ca thermometry using Caribbean coral Montastraea annularis: Geochemistry, Geophysics, Geosystems, v. 3, no. 11, 8402, doi:10.1029/2002GC000306, 2002.

Toscano, M.A., and Lundberg, J., 1998, Early Holocene sea-level record from submerged fossil reefs on the southeast Florida margin: Geology, v. 26, p. 255-258.

Veron, JEN, 2000, Corals of the World: v. 1-3, Australia: Australian Institute of Marine Sciences and CRR Qld Pty Ltd.

Weber, J.N., 1973, Incorporation of strontium into reef coral skeletal carbonate: Geochimica et Cosmochimica Acta, v. 37, p. 2173-2190. 